\title{
STUDI TENTANG PENERAPAN TEKNIK BERTANYA PROBING TERHADAP KEMAMPUAN KOMUNIKASI MATEMATIS SISWA PADA PEMBELAJARAN MATEMATIKA DI KELAS X.1 SMAN 1 LUBUK SIKAPING
}

\author{
Heru Maulana ${ }^{1)}$ \\ Staf Pengajar Jurusan Matematika, FMIPA Universitas Negeri Padang \\ herumaulana0203@gmail.com
}

\begin{abstract}
The low result of mathematics learning outcomes of students in grade X.1 SMAN 1 Lubuk Sikaping can be caused by the low ability of students' mathematical communication. Generally, students is feeling difficult to express the ideas, solutions of a problem, whether it can be an answer or a response to what he or she thinks is poorly understood. One of the solution to solve this problem is by implementing probing technique which is a learning method by using questioning techniques that are digging knowledge of students. The purpose of this study is to describe the ability of students to communicate the idea mathematically and to know the student learning outcomes during the application of probing techniques in learning mathematics grade X.1 SMAN 1 Lubuk Sikaping. This type of research is pre-experimented with The One-Shot Case Study design. The subject of this research is the students of grade X.1 SMAN 1 Lubuk Sikaping registered in second semester of academic year 2010/2011. Data processing of students' mathematical communication ability is by determining the percentage of the improvement of each indicator on observation sheet in every meeting and also supported by data from the interview. The results of this study illustrate that mathematical communication skills of students have increased from each meeting by using probing techniques, generally. As the results of learning mathematics after using the probing technique is good because 25 students (75.75\%) of 33 students class X.1 SMAN 1 Lubuk Sikaping already reached Minimal Completeness Limit which has been appointed by SMAN 1 Lubuk Sikaping (75).
\end{abstract}

Keywords : Probing Technique, Mathematical Communication Ability, Mathematics Learning

\section{PENDAHULUAN}

Matematika merupakan salah satu alat bantu untuk menjelaskan fenomena-fenomena baik di alam, maupun kehidupan di masyarakat. Penguasaan matematika yang baik merupakan dasar yang kuat untuk mempelajari bidang studi yang lainnya. Namun fakta menunjukkan bahwa matematika merupakan pelajaran yang kurang disukai.

Berdasarkan observasi yang dilakukan di SMAN 1 Lubuk Sikaping, diungkapkan bahwa siswa kurang berminat, bergairah, cenderung pasif dalam mempelajari matematika, kurangnya respon yang diberikan siswa terhadap pertanyaaan dan penjelasan guru, kurang aktifnya siswa untuk mengkomunikasikan ide dan gagasannya, serta perhatian siswa pada saat pembelajaran berlangsung yang tidak fokus. Dampak lebih lanjut dari keadaan ini adalah munculnya aktivitas negatif siswa selama proses pembelajaran, seperti mengganggu teman saat guru menjelaskan, mengobrol, diam saja ketika ditanya guru, dan lain sebagainya.
Berdasarkan realita tersebut, hal yang menjadi perhatian penting dalam pembelajaran matematika adalah masalah komunikasi matematis siswa. Hal ini tidak lain dipicu oleh ketidakberanian siswa untuk bertanya kepada guru walaupun sebenarnya mereka mempunyai masalah. Begitu pula halnya dalam menjawab pertanyaan, berpendapat, dan mengkomunikasikan idenya.

Penyebab lainnya adalah perasaan siswa yang berlebihan akan suatu hal, seperti ia merasa akan dimarahi oleh guru apabila jawabannya salah dan juga merasa malu kepada temannya. Sehingga hal inilah yang menyebabkan rendahnya keberanian siswa untuk mau mengkomunikasikan apa yang dipikirkannya.

Fakta lain yang ditemukan adalah siswa hanya memberikan jawaban akhir saja tanpa dapat memberikan alasan atas jawabannya. Kebanyakan siswa mengerjakan dengan cara singkat setiap masalah yang diberikan sehingga langkah-langkah penyelesaian soal tidak terlihat. 
Hal ini berakibat siswa tidak terbiasa mengkomunikasikan jawabannya secara matematis.

Kondisi di atas mengakibatkan apa yang menjadi tujuan dari pembelajaran matematika belum bisa tercapai secara maksimal. Di antara tujuan pembelajaran matematika yang dijelaskan dalam Depdiknas (2005 : 22) yang hendak dicapai adalah :

1. melatih cara berpikir dan bernalar dalam menarik kesimpulan.

2. mengembangkan aktivitas belajar kreatif yang melibatkan imajinasi, intuisi, dan penemuan dengan mengembangkan pemikiran divergen, orisinil, rasa ingin tahu, membuat prediksi dan dugaan, serta mencoba-coba.

3. mengembangkan kemampuan memecahkan masalah.

4. mengembangkan kemampuan menyampaikan informasi atau mengkomunikasikan gagasan antara lain melalui pembicaraan lisan, catatan, grafik, peta, diagram dalam menjelaskan gagasan.

Oleh karena itu untuk mengatasi permasalahan tersebut perlu adanya pembaharuan dalam pembelajaran matematika. Guru diharapkan dapat mendesain pembelajaran yang membuat seluruh siswa aktif dan berkesempatan mengembangkan potensi yang ada pada dirinya. Di antara cara yang perlu diperbaiki guru adalah melalui perubahan strategi pengajaran, terutama dalam hal keterampilan dasar mengajar. Sesuai dengan tujuan awal yaitu agar siswa mampu mengkomunikasikan ide-idenya, maka salah satu keterampilan yang perlu diperhatikan adalah keterampilan bertanya.

Dalam National Council of Teachers of Mathematics (NCTM, 2000: 60) dijelaskan bahwa komunikasi merupakan bagian yang esensial dari matematika dan pendidikan matematika. Tanpa adanya komunikasi yang baik, maka perkembangan dari matematika akan terhambat. Hal ini menunjukkan bahwa komunikasi bermanfaat untuk mengingatkan siswa bersama-sama dengan guru dalam merespon suatu pembelajaran. NCTM (2000: 60-61) juga merekomendasikan kemampuan komunikasi matematik yang perlu ada dalam diri siswa agar mereka dapat : a. Memodelkan situasi dengan lisan, tertulis, gambar, grafik, dan secara aljabar.

b. Merefleksikan dan mengklasifikasikan dalam berpikir mengenai gagasangagasan matematika dalam berbagai situasi.

c. Mengembangkan pemahaman terhadap gagasan-gagasan matematika termasuk peranan definisi-definisi dalam matematika.

d. Menggunakan keterampilan membaca, mendengar, dan melihat untuk menginterpretasikan dan mengevaluasi gagasan matematika.

e. Mengkaji gagasan matematika melalui konjektur dengan alasan yang meyakinkan"

Menurut Mulyasa (2009: 70) keterampilan bertanya merupakan salah satu dari kemampuan dasar mengajar yang harus dimiliki guru. Melalui keterampilan bertanya akan tercipta pembelajaran yang efektif dan menyenangkan, karena hampir setiap tahap pembelajaran, guru harus memberikan pertanyaan, dan juga kualitas pertanyaan yang diajukan guru harus diperhitungkan sebab akan menentukan kualitas jawaban yang diberikan siswa. Setiap pertanyaan yang diberikan kepada siswa harus dievaluasi sejauh mana pengetahuan siswa dan telah seberapa banyak teori dan materi pelajaran yang dikuasai siswa dan kemampuannya dalam memecahkan berbagai persoalan yang berhubungan dengan yang dipelajarinya.

Selanjutnya Sugeng Prayitno dalam Suherman (2003: 108) menjelaskan bahwa dalam proses pembelajaran, bertanya memegang peranan penting, sebab pertanyaan yang tersusun dengan baik dengan teknik pelontaran yang tepat akan :

a. Meningkatkan partisipasi siswa dalam kegiatan belajar mengajar.

b. Membangkitkan minat dan rasa ingin tahu siswa terhadap suatu masalah yang sedang dibicarakan.

c. Mengembangkan pola berpikir dan cara belajar aktif dari siswa yang bersesuaian, seba berpikir itu sendiri sesungguhnya adalah bertanya.

d. Menuntun proses berpikir siswa, sebab pertanyaan yang baik akan membantu jawaban yang baik.

e. Memusatkan perhatian siswa terhadap masalah yang sedang dibahas." 
Keterampilan bertanya yang dimaksud pada penelitian ini adalah teknik probing, yaitu teknik bertanya yang bersifat menggali jawaban siswa sehingga didapat jawaban yang lebih lanjut dari siswa tersebut. Menurut Wijaya, dalam (http://www.sundayana.web.id/efektifitasbelajar-mengajar-matematika-dengan-teknikprobing) dijelaskan bahwa teknik probing adalah suatu teknik dalam pembelajaran dengan cara mengajukan satu seri pertanyaan untuk membimbing pelajar/ siswa menggunakan pengetahuan yang telah ada pada dirinya guna memahami gejala atau keadaan yang sedang diamati sehingga terbentuk pengetahuan baru. Sehingga teknik probing diawali dengan menghadapkan siswa pada situasi baru.

Menurut Cooper dalam Walfurqan ( 2009:

16) mengemukakan bahwa ada beberapa aktivitas pada teknik probing yang dapat dilakukan, yaitu:

a. Klarifikasi, siswa diminta menjelaskan jawabannya dengan kata-kata atau kalimat lain, sehingga jawabannya menjadi lebih baik.

b. Meminta alasan, siswa diminta memberikan alasan atau bukti untuk menunjang jawabannya.

c. Meminta kesepakatan pandangan, guru memberi kesempatan kepada siswa lain untuk menyatakan pendapatnya terhadap jawaban yang diberikan temannya. Penolakan atau persetujuan yang diberikan harus disertai alasan, sehingga diperoleh jawaban yang benar.

d. Meminta ketepatan jawaban siswa, siswa diminta meninjau kembali jawaban yang diberikannya jika jawaban masih belum tepat.

e. Meminta jawaban yang lebih relevan, jika jawaban yang diberikan oleh siswa tidak relevan dengan pertanyaan yang diajukan, maka guru dapat meminta siswa mengemukakan jawaban dengan kata-kata lain, sehingga jawaban yang diberikan benar.

f. Meminta contoh, jika jawaban yang diberikan samar-samar atau terlalu luas, maka guru dapat meminta siswa memberi contoh tentang apa yang dimaksudnya.

g. Meminta jawaban yang lebih kompleks, jika jawaban yang dikemukakan siswa masih dapat ditingkatkan menjadi lebih sempurna atau dalam, maka guru dapat meminta siswa memberikan penjelasan atau mengemukakan ide-ide penting dalam jawabannya.
Siswa dapat mengembangkan kualitas jawaban mereka dengan menggunakan teknik probing. Dalam pembelajaran, pertanyaan dengan menggunakan teknik probing ini bersifat terstruktur, sehingga siswa dapat mengikuti proses pembelajaran dengan baik dan bisa mengembangkan ide-idenya dengan baik pula. Selanjutnya diharapkan meningkatnya kemampuan komunikasi dan hasil belajar siswa. Oleh karena itu dilakukan suatu penelitian tentang peningkatan kemampuan komunikasi matematis siswa dengan teknik probing pada pembelajaran matematika di kelas X.1 SMAN 1 Lubuk Sikaping tahun pelajaran 2010/ 2011.

\section{METODE PENELITIAN}

Jenis penelitian ini adalah penelitian praeksperimen, yang melibatkan satu kelas saja tanpa adanya kelas kontrol. Adapun model rancangan penelitian ini adalah "The One Shot Case Study". Pada penelitian ini, teknik bertanya probing diterapkan pada kelas yang menjadi subjek penelitian untuk melihat peningkatan kemampuan komunikasi matematis siswa.

Subjek penelitian ini adalah siswa kelas X.1 SMAN 1 Lubuk Sikaping tahun pelajaran 2010/ 2011 yang berjumlah 33 orang. Pemilihan kelas ini sebagai subjek penelitian adalah karena kelas ini merupakan kelas unggul yang telah melalui seleksi penerimaan siswa baru yang ketat. Namun berdasarkan keterangan dan data yang penulis dapatkan dari guru yang mengajar, kelas ini kurang aktif dan kurang berani serta mengalami kesulitan dalam mengkomunikasikan idenya secara matematis dalam menanggapi pertanyaan dan rangsangan yang diberikan guru walaupun mereka mengerti dan paham dengan materi yang diberikan.

Instrumen yang digunakan dalam penelitian ini adalah lembar observasi, wawancara dan tes hasil belajar matematika siswa. Lembar observasi digunakan untuk mencatat peningkatan yang terjadi selama proses pembelajaran dan wawancara digunakan untuk memperkuat hasil yang diperoleh dari lembar observasi. Sedangkan untuk melihat hasil dari proses pembelajaran menggunakan teknik bertanya probing, dilakukan tes akhir pada akhir penelitian.

Data yang didapatkan dari penelitian ini diolah secara kualitatif dan kuantitatif. Data kuantitatif berupa pemahaman siswa terhadap konsep yang dapat dilihat dari tes hasil belajar 
dan kemudian data ini diolah dengan perhitungan statistik. Sedangkan data kualitatif adalah berupa aktivitas siswa yang diperoleh dari pengamatan yang dituliskan pada lembar observasi dan hasil wawancara.

\section{HASIL DAN PEMBAHASAN}

Pelaksanaan pembelajaran matematika pada kelas X.1 SMAN 1 Lubuk Sikaping dengan menggunakan teknik bertanya probing diamati dengan menggunakan instrumen lembar observasi dan kemudian diperkuat dengan hasil wawancara. Berdasarkan observasi yang dilakukan pada penelitian ini, diperoleh hasil bahwa terjadi peningkatan kemampuan komunikasi matematis dan aktivitas belajar siswa selama proses pembelajaran berlangsung. Hal ini dapat dilihat gambar-gambar berikut :

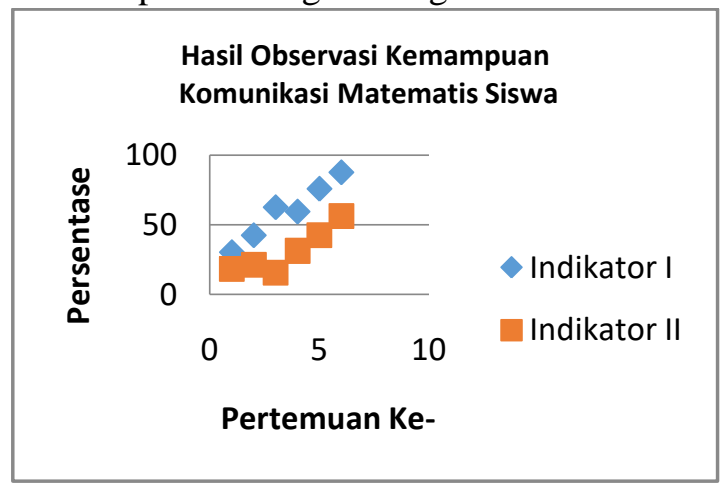

Gambar 1: Hasil Observasi Indikator I dan II

Gambar 1 di atas menampilkan persentase aktivitas siswa dalam hal memodelkan atau menyajikan pernyataan matematika dengan lisan, tertulis, grafik, gambar, atau secara aljabar mengalami perubahan dari pertemuan pertama sampai pertemuan keenam. Persentase aktivitas siswa pada pertemuan pertama mengalami kenaikan hingga pertemuan ketiga. Namun pada pertemuan ke empat mengalami penurunan dan meningkat lagi pada pertemuan kelima dan keenam.

Pada aktivitas siswa dalam hal menggunakan keterampilan membaca, mendengar, melihat untuk mengungkapkan atau mengevaluasi gagasan matematika juga mengalami perubahan dari pertemuan pertama sampai pertemuan keenam. Persentase aktivitas siswa mengalami peningkatan sampai pertemuan kedua. Namun mengalami penurunan pada pertemuan ketiga dan meningkat lagi dari pertemuan keempat sampai pertemuan keenam.

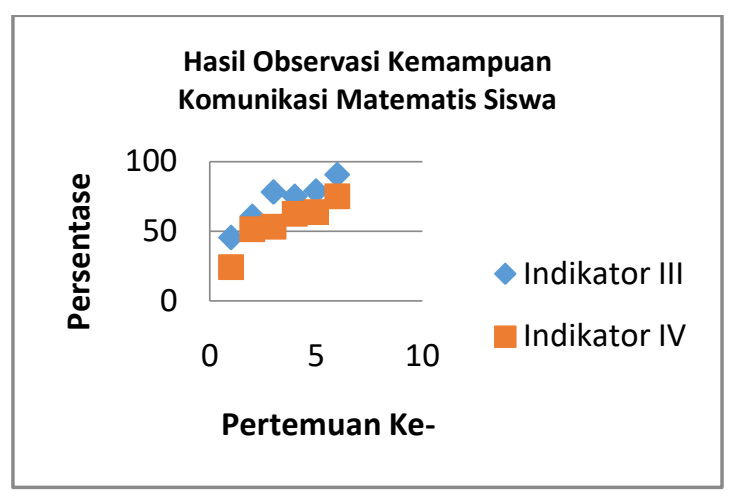

Gambar 2 : Hasil Observasi Indikator III dan IV

Gambar 2 di atas menampilkan persentase aktivitas siswa dalam hal menyampaikan ide atau gagasan saat pembelajaran serta berani menjawab pertanyaan yang diberikan guru mengalami perubahan pada setiap pertemuan. Persentase aktivitas siswa pada pertemuan pertama mengalami peningkatan sampai pertemuan ketiga. Pada pertemuan keempat mengalami penurunan. Dan pada pertemuan kelima dan keenam mengalami kenaikan.

Pada aktivitas siswa dalam hal berani membenarkan atau menanggapi jawaban atau gagasan teman juga mengalami peningkatan dari pertemuan pertama sampai pertemuan keenam. Persentase pada indikator ini selalu mengalami peningkatan pada setiap pertemuannya.

Untuk indikator kelima dan keenam, dapat dilihat pada gambar 3 di bawah ini :

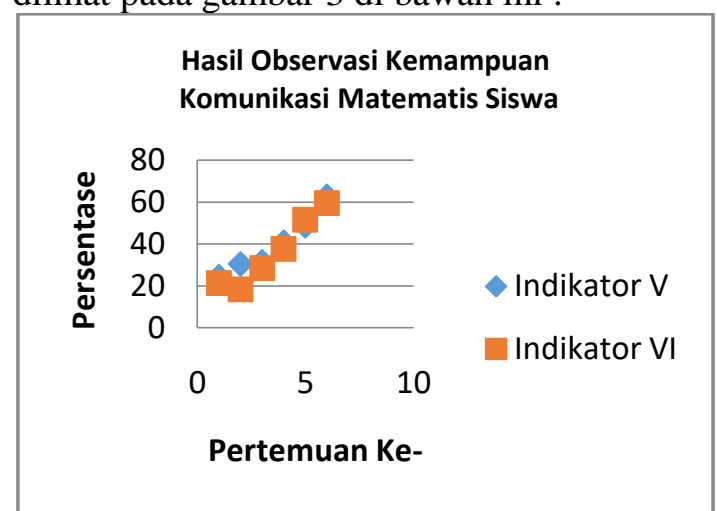

Gambar 3: Hasil Observasi Indikator V dan VI

Gambar 3 di atas menampilkan persentase aktivitas siswa dalam hal memberikan jawaban yang kompleks dan dilengkapi contoh juga mengalami peningkatan dari pertemuan pertama sampai pertemuan keenam.

Pada aktivitas siswa dalam hal menggunakan bahasa yang jelas, mengkomunikasikannya secara matematis atau mengembangkannya dengan bahasa sendiri juga mengalami perubahan dari pertemuan pertama sampai pertemuan keenam. Persentase aktivitas 
siswa pada pertemuan pertama mengalami penurunan hingga pertemuan kedua. Namun pada pertemuan ketiga sampai pertemuan keenam terus mengalami peningkatan.

Hasil observasi untuk indikator ketujuh dan kedelapan, dapat dilihat pada gambar 4 di bawah ini ;

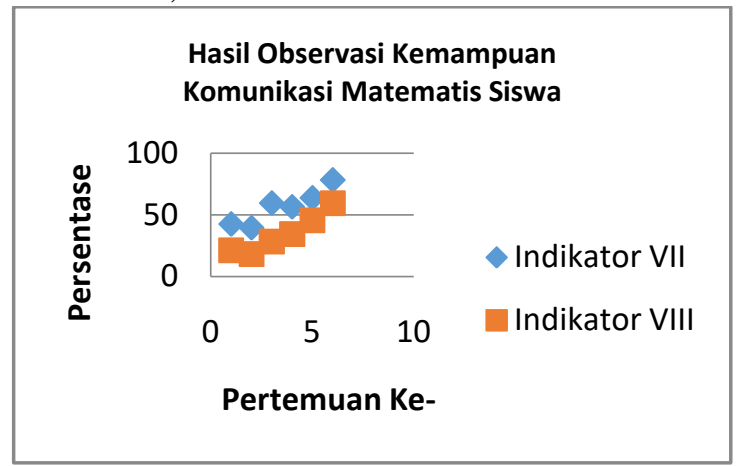

Gambar 4: Hasil Observasi Indikator VII dan VIII

Gambar 4 di atas menampilkan persentase aktivitas siswa dalam hal menarik kesimpulan, memberikan bukti, atau mengajukan solusi juga mengalami perubahan pada setiap pertemuannya. Pada pertemuan pertama persentase aktivitas siswa mengalami penurunan hingga pertemuan kedua dan keempat. Namun pada pertemuan ketiga, kelima dan keenam mengalami peningkatan lagi.

Pada aktivitas siswa dalam hal memeriksa kesahihan atau kebenaran argumen matematika juga mengalami perubahan dari pertemuan pertama sampai pertemuan keenam. Pada pertemuan pertama persentase aktivitas siswa mengalami penurunan hingga pertemuan kedua. Lalu untuk pertemuan ketiga dan seterusnya sampai pertemuan keenam mengalami peningkatan.

Hasil observasi untuk indikator kesembilan dan kesepuluh, dapat dilihat pada gambar 5 di bawah ini :

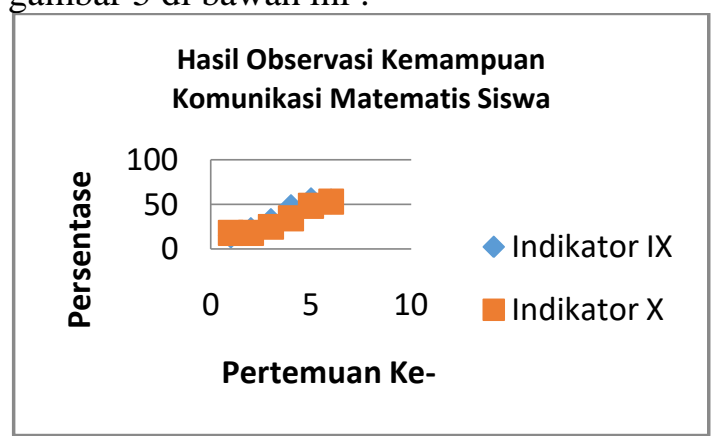

Gambar 5: Hasil Observasi Indikator IX dan X

Gambar 5 di atas menampilkan persentase aktivitas siswa dalam hal mengembangkan pemahaman tentang matematika dari pola atau sifat dan definisi yang ada, mengalami perubahan dari pertemuan pertama sampai pertemuan keenam. Namun mengalami penurunan pada pertemuan keenam.

Pada aktivitas siswa dalam hal memberikan dugaan dari permasalahan yang diberikan juga mengalami peningkatan pada setiap pertemuannya. Untuk pertemuan pertama dan kedua persentase aktivitas siswa adalah tetap, lalu mengalami peningkatan pada pertemuan ketiga sampai pertemuan keenam.

Selanjutnya, untuk memperkuat hasil yang diperoleh pada lembar observasi, maka dilakukanlah wawancara. Pada wawancara ini penulis langsung mewawancarai responden. Responden dari wawancara ini adalah beberapa orang siswa pada subjek penelitian. Materi dari wawancara didasarkan pada kebutuhan data yang diperlukan yang tidak didapatkan pada lembaran observasi.

Berdasarkan wawancara yang telah penulis lakukan terhadap 9 orang siswa dari kelas subjek penelitian yang terdiri atas 3 orang dari kelompok berkemampuan tinggi, 3 orang dari kelompok berkemampuan sedang, dan 3 orang dari kelompok berkemampuan rendah, diperoleh hasil bahwa pembelajaran matematika dengan teknik bertanya probing disukai dan disenangi oleh siswa. Tidak hanya siswa-siswa yang diwawancarai saja, namun juga berdasarkan keterangan dari responden, pada umumnya teman satu kelas mereka juga menyukai pembelajaran dengan teknik probing. Walaupun beberapa orang siswa ada yang mengeluhkan bahwa mereka merasa sedikit kewalahan dalam menjawab pertanyaan yang diajukan guru, tapi mereka tetap menyukai pembelajaran dengan teknik bertanya ini karena mereka merasa tertantang untuk bersaing dengan teman-temannya.

Sementara itu untuk melihat keberhasilan hasil belajar siswa maka dilaksanakanlah tes akhir pada akhir penelitian. Pokok bahasan yang diujikan yaitu Perbandingan dan Fungsi Trigonometri. Tes Akhir ini terdiri atas 7 butir soal essay dan dilaksanakan dalam waktu 80 menit. Setelah tes akhir dilaksanakan, diperoleh data mengenai hasil belajar matematika siswa dengan teknik bertanya probing, dan juga kemampuan siswa dalam mengkomunikasikan idenya dalam jawaban essay yang dikerjakannya sehingga diketahui ketuntasan hasil belajar siswa. Hasil analisis tentang data tes akhir belajar dapat dilihat pada Tabel 1 berikut : 
Tabel 1 : Hasil Analisis Data Tes Akhir

\begin{tabular}{|c|c|c|c|c|}
\hline $\mathrm{N}$ & $\bar{X}$ & $\mathrm{~S}$ & $X_{\max }$ & $X_{\min }$ \\
\hline 33 & 75,97 & 11,68 & 95 & 50 \\
\hline
\end{tabular}

Jumlah siswa yang tuntas pada tes akhir matematika dapat dilihat pada Tabel 2 berikut :

Tabel 2 : Persentase Jumlah Siswa yang Tuntas pada Tes akhir

\begin{tabular}{|c|c|c|}
\hline Jumlah Siswa & $<75$ & $\geq 75$ \\
\hline 33 & $24.25 \%$ & $75.75 \%$ \\
\hline
\end{tabular}

Berdasarkan Tabel 2 di atas dapat diketahui bahwa dari 33 orang siswa yang mengikuti tes akhir belajar, dinyatakan bahwa $75.75 \%$ siswa telah mencapai ketuntasan dalam pokok bahasan trigonometri, sedangkan $24.25 \%$ lainnya belum mencapai ketuntasan.

Berdasarkan tes akhir belajar yang telah dilaksanakan terlihat bahwa dari 33 orang siswa yang telah mengikuti tes tersebut, dinyatakan bahwa sebanyak 25 orang telah tuntas dalam proses pembelajaran yang dilaksanakan karena telah memenuhi Kriteria Ketuntasan Minimal (KKM) yang ditetapkan oleh SMAN 1 Lubuk Sikaping yaitu 75. Sedangkan 8 orang lainnya dinyatakan belum tuntas dalam belajar karena memperoleh nilai tes akhir yang berada di bawah KKM, seperti yang terlihat dalam lampiran 11.

Berdasarkan Tabel 1 di atas terlihat bahwa rata-rata nilai tes akhir yang diperoleh adalah 75,79 dengan nilai tertinggi 95 dan nilai terendah adalah 50. Dari data tersebut dapat dilihat kemampuan siswa dalam kelas X.1 SMAN 1 Lubuk Sikaping cukup beragam.

Berdasarkan Tabel 2 di atas dapat dilihat bahwa persentase siswa kelas X.1 SMAN 1 Lubuk Sikaping yang telah mencapai ketuntasan dalam belajar adalah sebesar $75,75 \%$.

Berdasarkan deskripsi dan analisis data yang telah diungkapkan di atas terlihat bahwa secara garis besar persentase kemampuan komunikasi matematis siswa selama pembelajaran dengan menggunakan teknik probing telah mencapai peningkatan walau belum merata disetiap pertemuannya.

Indikator observasi yang pertama yaitu memodelkan atau menyajikan pernyataan matematika dengan lisan, tertulis, grafik, gambar, dan secara aljabar memperlihatkan bahwa pada setiap pertemuan kemampuan siswa telah mengalami peningkatan. Dari sini dapat disimpulkan bahwa siswa telah memperhatikan penjelasan guru dan dibimbing dengan pertanyaan-pertanyaan probing yang diberikan. Sehingga siswa dapat mengkontruksi persoalan yang diberikan kedalam bahasa matematika.

Indikator observasi yang kedua yaitu menggunakan keterampilan membaca, mendengar atau melihat untuk mengungkapkan dan mengevaluasi gagasan matematika memperlihatkan bahwa siswa sudah mulai terbiasa dan terlatih dalam menggunakan indera mereka untuk menangkap dan menafsirkan apa yang mereka dengar dan lihat kedalam ide dan gagasan matematika dengan tetap dipandu oleh guru. Sehingga kemampuan siswa untuk menafsirkan apa yang mereka dapatkan sudah mengalami peningkatan.

Indikator observasi yang ketiga yaitu siswa menyampaikan ide atau gagasan saat pembelajaran serta berani menjawab pertanyaan yang diberikan guru menunjukkan bahwasanya pada setiap pertemuan sudah ada peningkatan aktivitas dan keberanian siswa dalam merespon pertanyaan yang diberikan guru. Siswa sudah berani membuka diri untuk menanggapi masalah dan persoalan yang ada. Sehingga kemampuan siswa dalam berkomunikasi secara matematis sudah mengalami kemajuan walaupun jawaban yang disampaikan siswa masih ada yang belum sesuai dengan yang diharapkan, tapi tetap dibimbing untuk mendapatkan jawaban yang benar.

Indikator observasi yang keempat yaitu berani membenarkan atau menanggapi jawaban atau gagasan teman menunjukkan bahwasanya sudah muncul rasa keberanian siswa untuk mengungkapkan gagasan dan idenya. Selain itu juga disebabkan oleh rasa kompetitif siswa untuk menjadi lebih unggul dari temantemannya.

Indikator observasi yang kelima yaitu memberikan jawaban yang kompleks dan dilengkapi contoh menunjukkan bahwa pada setiap pertemuannya selalu mengalami peningkatan yang tidak terlalu signifikan. Sehingga dapat disimpulkan pada setiap pertemuannya selalu ada keinginan siswa untuk menjawab pertanyan-pertanyan guru secara lengkap dan disertai contoh yang ada.

Indikator observasi yang keenam yaitu menggunakan bahasa yang jelas, mengkomunikasikannya secara matematis, atau mengembangkannya dengan bahasa sendiri menunjukkan bahwa siswa semakin lama sudah semakin terbiasa mnyampaikan idenya dengan bahasa sendiri karena selalu dipancing dengan 
pertanyaan-pertanyaan probing. Dan dapat disimpulkan kemampuan komunikasi matematis siswa sudah mulai menggunakan bahasa sendiri dan jelas karena selalu dipandu guru dengan pertanyaan-pertanyaan.

Indikator observasi yang ketujuh yaitu menarik kesimpulan, memberikan bukti, atau mengajukan solusi menunjukkan bahwa setelah mempelajari beberapa materi siswa sudah mulai memahami tentang trigonometri sehingga untuk materi selanjutnya mereka sudah bisa membiasakan diri. Contohnya setelah siswa memahami trigonometri sudut pada keempat kuadran maka mereka akan lebih mudah menguasai persamaan trigonometri.

Indikator observasi yang kedelapan adalah memeriksa kesahihan atau kebenaran argumen matematika menunjukkan bahwa kemampuan siswa dalam menganalisis kebenaran sebuah argumen atau pernyataan matematika selalu meningkat pada setiap pertemuan.

Indikator observasi yang kesembilan yaitu mengembangkan pemahaman tentang matematika dari pola atau sifat dan definisi yang ada menunjukan bahwa adanya usaha siswa untuk memahami matematika dan mengembangkan wawasannya melalui pola, sifat, dan definisi yang ada. Sehingga kemampuan siswa dalam mengembangkan ideidenya berkembang dengan baik. Sebagai contoh pada subbab identitas trigonometri, siswa bisa menemukan identitas lainnya dari satu identitas yang diberikan.

Indikator observasi yang kesepuluh yaitu memberikan dugaan menunjukan bahwa siswa sudah mulai bisa membuat sebuah dugaan dari persoalan yang diajukan. Jadi kemampuan siswa dalam menganalisis sebuah soal dan membuat dugaan penyelesaiannya sudah meningkat, sehingga kemampuan komunikasi matematis siswa dalam menterjemahkan maksud soal sudah baik.

Selain itu berdasarkan wawancara yang telah penulis lakukan terhadap 9 orang siswa dari kelas subjek penelitian yang terdiri atas 3 orang dari kelompok berkemampuan tinggi, 3 orang dari kelompok berkemampuan sedang, dan 3 orang dari kelompok berkemampuan rendah maka diperoleh hasil bahwa pembelajaran matematika dengan teknik probing disukai dan disenangi oleh siswa. Tidak hanya siswa-siswa yang diwawancarai saja, namun juga berdasarkan keterangan dari responden rata-rata teman satu kelas mereka menyukai pembelajaran dengan metode bertanya.

Begitu juga hasil yang ditunjukkan oleh deskripsi dan analisis data pada tes akhir belajar yang telah dilaksanakan pada kelas X.1 SMAN 1 Lubuk Sikaping diperoleh hasil belajar matematika siswa secara keseluruhan adalah baik pada pokok bahasan trigonometri. Dari 33 orang siswa yang mengikuti tes, terdapat 25 orang siswa yang telah mencapai KKM yang ditetapkan SMAN 1 Lubuk Sikaping yaitu 75 atau sekitar $75.75 \%$. Sedangkan 8 orang siswa lainnya belum mencapai ketuntasan belajar karena nilai yang diperoleh masih berada dibawah KKM atau sekitar $24.25 \%$. Dengan demikian dapat dikatakan bahwa pembelajaran matematika dengan menggunakan teknik probing dapat meningkatkan kemampuan komunikasi matematis siswa beserta hasil belajar siswa.

Berdasarkan pengamatan yang dilakukan selama penelitian, maka dapat ditarik kesimpulan secara umum bahwasanya kemampuan komunikasi matematis siswa yang dinilai dari aktivitas-aktivitas selama pembelajaran seperti di atas dengan menggunakan teknik bertanya probing mengalami peningkatan pada pokok bahasan Trigonometri. Kemampuan ini tidak lagi hanya mendengar penjelasan dari guru saja lalu mencatatnya, tetapi siswa lebih dituntut untuk aktif, berani, dan mampu mengkomunikasikan ide-idenya, berdasarkan pertanyaan-pertanyaan probing yang diajukan guru sehingga siswa dapat lebih memahami materi karena dia sendiri yang berusaha menemukannya.

\section{KESIMPULAN}

Berdasarkan analisis terhadap data hasil penelitian maka dapat ditarik kesimpulan bahwa pembelajaran matematika dengan menggunakan teknik bertanya probing pada kelas X.1 SMAN 1 Lubuk Sikaping meningkat dan kemampuan komunikasi matematis siswa dalam belajar juga semakin baik.

Selain itu pembelajaran matematika dengan menggunakan teknik bertanya probing pada kelas X.1 SMAN 1 Lubuk Sikaping menjadikan hasil belajar matematika siswa menjadi lebih baik yang terlihat dari hasil belajar siswa yaitu 25 orang siswa $(75.75 \%)$ dari semua siswa telah mencapai ketuntasan belajar. 
DAFTAR PUSTAKA

Departemen Pendidikan Nasional. 2005. Matematika. Jakarta: Direktorat Jenderal Pendidikan Dasar dan Menengah.

Mulyasa. 2009. Menjadi Guru Profesional. Bandung : Remaja Rosdakarya

National Council of Teachers of Mathematics. 2000. Principles and Standards for School Mathematics. NCTM: Reston VA.

Suherman, Erman. 2003. Strategi Pembelajaran Matematika Kontemporer. Bandung : JICA UPI.

Walfurqan. 2009. "Teknik Probing dalam Pembelajaran Matematika untuk Meningkatakan Pemahaman Konsep dan Aktivitas Siswa Kelas VIII SMPN 17 Padang ". Skripsi. Universitas Negeri Padang.

Walpole, Ronald E. 1997. Pengantar Statistika. Jakarta: PT Gramedia Pustaka Utama.

Wijaya. 2009. "Teknik Probing dan Prompting". (http://www.sundayana.web.id/efektifita s-belajar-mengajar-matematika-denganteknik-probing. Diakses tanggal 8 September 2010. 